\title{
A Perspectival Account of Acedia in the Writings of Kierkegaard
}

\author{
Jared Brandt ${ }^{1, *}$, Brandon Dahm ${ }^{2, *}$ and Derek McAllister ${ }^{3, *}$ \\ 1 Department of Philosophy, Dallas Baptist University, Dallas, TX 75211, USA \\ Department of Philosophy, Franciscan University of Steubenville, Steubenville, OH 43952, USA \\ 3 Department of Philosophy, Baylor University, Waco, TX 76798, USA \\ * Correspondence: jaredb@dbu.edu (J.B.); bdahm@franciscan.edu (B.D.); derek_mcallister@baylor.edu (D.M.)
}

Received: 2 January 2020; Accepted: 28 January 2020; Published: 10 February 2020

\begin{abstract}
Søren Kierkegaard is well-known as an original philosophical thinker, but less known is his reliance upon and development of the Christian tradition of the Seven Deadly Sins, in particular the vice of acedia, or sloth. As acedia has enjoyed renewed interest in the past century or so, commentators have attempted to pin down one or another Kierkegaardian concept (e.g., despair, heavy-mindedness, boredom, etc.) as the embodiment of the vice, but these attempts have yet to achieve any consensus. In our estimation, the complicated reality is that, in using slightly different but related concepts, Kierkegaard is providing a unique look at acedia as it manifests differently at different stages on life's way. Thus, on this "perspectival account", acedia will manifest differently according to whether an individual inhabits the aesthetic, ethical, or religious sphere. We propose two axes for this perspectival account. Such descriptions of how acedia manifests make up the first, phenomenal axis, while the second, evaluative axis, accounts for the various bits of advice and wisdom we read in the diagnoses of acedia from one Kierkegaardian pseudonym to another. Our aim is to show that Kierkegaard was not only familiar with the concept of acedia, but his contributions helped to develop and extend the tradition.
\end{abstract}

Keywords: acedia; sloth; Deadly Sins; Kierkegaard; despair; boredom; aesthetic; ethical; religious; immediacy

\section{Introduction}

For the Christian tradition, the vice of acedia $[\alpha \kappa \eta \delta i \alpha]$ has been one of the most serious vices, featuring prominently in lists of the Deadly Sins from Evagrius and Cassian to Gregory and Aquinas. Traditionally, acedia has been characterized as a slothfulness, weariness, or even sorrow, in particular with respect to one's religious duties and love for God. It was said to manifest in one of two ways: a kind of listlessness (hence the common translation of sloth) or restlessness. ${ }^{1}$ Acedia has enjoyed a renewal of interest over the last 100 or so years, ${ }^{2}$ this after theoretical analyses of acedia having all but disappeared since the High Scholastic period. ${ }^{3}$ There are many possible explanations one could give of

\footnotetext{
See (Cassian 1894), Institutes, X.VIII, “ ... those who will not work are always restless, owing to the fault of idleness."

The boundaries, as with anything in history, are not well-defined. We have in mind, firstly, Anglican Bishop Paget (1891). About mid-century, there is Josef Pieper (Pieper 1986; Pieper 1952) and Wenzel (1960), among others. Acedia has been of interest even to famous literary figures like Aldous Huxley, who discusses a secular form of the vice in his essay "Accidie" (Huxley 1928); Evelyn Waugh, who portrays acedia in religious terms, albeit from the perspective of an agnostic, in his Brideshead Revisited (Waugh 1999); and T. S. Eliot, who, according to Colón (2011), threads the theologically robust form of acedia through his post-conversion works Murder in the Cathedral (Eliot 1935) and Four Quartets (Eliot 1948). As it turns out, T. S. Eliot even wrote the original English translation introduction to Pieper's (1952).

3 Discussions of its application in the life of the believer continued during the 14th-15th centuries in practical theological works like confessional instructions, catechetical handbooks, sermons, and encyclopedias for clergy. But even this change
} 
this fact, ${ }^{4}$ but we will not pursue this here. Instead, we will focus on one writer, Søren Kierkegaard, who precedes this recent renaissance, who himself paid close attention to the vicious side of human nature and whose erudition supplied him with the means to explore it.

At first glance, Kierkegaard's work is not an obvious place to turn to in a discussion of acedia; he uses the word 'acedia' only once. ${ }^{5}$ Nevertheless, there is good reason to think that some of the central phenomena he investigates are closely related to acedia. For instance, early on in the resurgent interest in acedia, Josef Pieper (Pieper 1986; Pieper 1952) uses, inter alia, Kierkegaardian concepts in his analysis of acedia. Since then, Kierkegaardian concepts have come to appear regularly in discussions of the vice. These discussions have been occasioned by discussion of the vice instead from thematic discussions of acedia in Kierkegaard. So, it is not surprising that there is no consensus regarding just which Kierkegaardian concept most neatly parallels acedia. Some writers, including Pieper, claim that one of the forms of despair in The Sickness Unto Death is acedia. ${ }^{6}$ Others identify the vice as the melancholy or depression [Tungsind] discussed in Either/Or. ${ }^{7}$ Still others see a connection between acedia and Kierkegaardian notions like boredom ${ }^{8}$ or spiritual trial. ${ }^{9}$ In our view, all of these proposals are, in some sense, correct. There are, in fact, strong parallels between each of these concepts and acedia. We see this as part of the very design of Kierkegaard's authorship: to subject specific phenomena (including acedia) to close scrutiny from diverse perspectives, the result of which is a more thorough analysis of the phenomena.

To be more precise, we argue for the following thesis. Beyond simply exhibiting a prior familiarity with acedia (both de dicto and de re), Kierkegaard's philosophical and theological categories also reveal his own novel contribution to the capital vices tradition in the form of extending and developing our understanding of acedia. To be clear, our thesis does not require that Kierkegaard deliberately intended to develop acedia as such, but that his own thinking reflects deep and extensive elements of older Chrisitan traditions, whether he encountered these through reading or ecclesial practice, such that in his thinking can be found a natural extension of the tradition on acedia. ${ }^{10}$ We call this novel contribution his perspectival analysis of acedia. The perspectives he considers are, in Kierkegaardian terminology: the aesthetic life, the ethical life, and the religious life. ${ }^{11}$ This perspectival analysis has two axes:

(i) phenomenal axis: the experience of acedia in different life stages, ${ }^{12}$

(ii) evaluative axis: the diagnoses of acedia from different life stages.

in emphasis reveals that theoretical discussions of acedia had long since subsided since the High Scholastic era. Cf. Wenzel (1960, pp. 174-81). Wenzel also sees in this change in acedia's emphasis a shift to external, particular, confessional "concrete faults, [rather than on] abstract states of mind" (p. 177).

4 For example, perhaps it is because the vice had characteristic beginnings in the monastic form of life, which itself faded from prominence; or perhaps the earlier Scholastic theoretical treatments had settled the issue (or maybe rather they were too obscure).

5 This came in a short journal entry in 1839. We will have more to say about this below. Apart from another, even shorter, journal entry in 1849 (NB10: 23 1849, SKS 21, 269), which is more of a mention than a use of the word, in connection with Bonaventure's work, there is no other significant interaction with the actual term. (We argue, of course, that he was interacting significantly with the concept under different terminology.)

6 See (Pieper 1986; Pieper 1952; DeYoung 2015).

7 See (Cappelørn 2008; Ferguson 1994).

8 See (Kuhn 1976; McDonald 2009; Pattison 2013).

9 See (Podmore 2011, 2013).

10 For example, “Kierkegaaard refers to pagan virtues as 'glittering vices' (SKS 9, 60; Kierkegaard 1995, WL 53; Kierkegaard 1980, SUD 46). The term, also used by other Church Fathers, is explicated in [Augustine's] Civitate dei [XIX, 25]" (Puchniak 2008, p. 13). Cf. Kierkegaard Research: Sources, Reception and Resources Volume 4, Kierkegaard and the Patristic and Medieval Traditions (2008) for more.

11 There is little doubt that a perspectival account of acedia can be offered, perhaps even has been offered (we can only speculate), using different developmental categories, but Kierkegaard's spheres lend themselves particularly well to showcasing this. As we shall see, it is important not to place too much weight on the stages/spheres as clear categories, as Kierkegaard sometimes lumps them together (SUD 45).

12 For shorthand, we sometimes will refer to these as "types of acedia", but to be sure, they are properly speaking a description of the phenomenal experience, or what-it-is-like, to be afflicted with acedia from the perspective of the aesthetic, ethical, and religious spheres, respectively. 
Thus, for example, the experience of acedia from the perspective of the aesthetic life (hereafter, "aesthetic acedia") is distinct from the experience of acedia from the perspective of the ethical life (hereafter "ethical acedia"), and so on. More than this, each of these can be diagnosed or evaluated from differing, higher perspectives (as depicted in Figure 1) ${ }^{13}$ : for instance, a diagnosis of aesthetic acedia as given from the aesthetic sphere is distinct from a diagnosis of aesthetic acedia as given from the ethical sphere. (Readers of Either/Or will recognize immediately that this is the difference between A's evaluation of himself and Judge Wilhelm's evaluation of A's condition.)

\begin{tabular}{|c|c|c|c|}
\hline Type & Aesthetic Acedia & Ethical Acedia & Religious Acedia \\
\hline $\begin{array}{c}\text { Experienced in: } \\
\text { (phenomenal axis) }\end{array}$ & Aesthetic Sphere & Ethical Sphere & Religious Sphere \\
\hline $\begin{array}{c}\text { Diagnosed from: } \\
\text { (evaluative axis) }\end{array}$ & $\begin{array}{c}\text { Aesthetic Perspective } \\
\text { Ethical Perspective } \\
\text { Religious Perspective }\end{array}$ & $\begin{array}{c}\text { Ethical Perspective } \\
\text { Religious Perspective }\end{array}$ & Religious Perspective \\
\hline
\end{tabular}

Figure 1. Kierkegaard's Perspectival Analysis of Acedia.

If our thesis is correct, we think it has residual benefit in that a perspectival account of acedia resolves the lack of consensus in the secondary literature we have mentioned above (viz., which Kierkegaardian concept most closely matches acedia).

In Section 2, we give a brief conceptual history of acedia as it appears in the Christian tradition from the Desert Fathers to the Scholastics. More than a simple overview, Section 2 is critical for showing the complexity of acedia-its object, its effects, its provenance, and its remedies-a complexity which must be grasped in order to see how it is beautifully interwoven through Kierkegaard's authorship. Sections 3 and 4 discuss Kierkegaard's analysis of acedia as it appears in two important works: Either/Or and The Sickness Unto Death, respectively. ${ }^{14}$ Across Kierkegaard's authorship, we see a portrait of acedia from different perspectives (life stages); and, hence, we see different aspects of acedia being emphasized depending on the work. Finally, in Section 5, we close with an evaluation of Kierkegaard's contribution to the Christian tradition on acedia.

\section{Acedia in the Christian Tradition}

Both Evagrius of Pontus (345-399) and John Cassian (360-435) included acedia in their lists of the eight "evil thoughts" [ $\lambda$ o $\gamma(\sigma \mu \mathrm{ol}, \text { logismoi }]^{15}$ or "principal faults"16_indeed, Evagrius calls it "the most

13 It seems that, at least in Kierkegaard's works, a lower sphere does not diagnose a higher. However, DeYoung (2009, p. 19) says, "when we read Brideshead Revisited by Evelyn Waugh, we see a portrait of the vice of sloth in explicitly religious terms (although narrated by an agnostic character)."

14 Space prohibits the consideration of more, but we think other works within the corpus can support the extension of our thesis: for instance, despair [Fortvivlelse] in Works of Love, the last two 'anxieties of the heathen' in Christian Discourses, and, Concept of Anxiety. In a longer version of the project, we propose that the various forms of anxiety discussed in Concept of Anxiety represent manifestations of acedia in the diverse life stages as follows: Anxiety of Spiritlessness (Aesthetic), Anxiety Defined Dialectically as Fate or Guilt (Ethical or Ethical-Religious), and Anxiety about the Good (Religious).

15 Vlachos (1994) explains the significance of these thoughts, or logismoi: "The Holy Fathers do not talk about concepts (skepsis) but about thoughts (logismoi) ... Conceptions are rational suggestions, while thoughts (logismoi) are rational suggestions combined with the appropriate stimuli and images brought in either by sight, by hearing, or by both" (p. 45). As such, "logismoi" taken generally need apply to sinful or bad thoughts, but the context here makes it clear that the Desert Fathers understand these eight logismoi as normatively bad.

16 Cf. Harmless (2004): Evagrius "calls them 'thoughts,' not sins" (p. 312; cf. 218). "[Evagrius's] list would become, with slight modification, the seven deadly sins and enjoy a venerable place in the spirituality of the Middle Ages ... The one who brought Evagrius's scheme to the Latin West was his disciple, John Cassian, who discussed them at length in two works, The Institutes and The Conferences" (p. 322). 
troublesome of all" (Praktikos, 28). The Desert Fathers often described acedia in terms of a daimon $[\delta \alpha i \mu \omega v]$ that brought a certain weariness or aversion to the work at hand:

“The demon of $\alpha \kappa \eta \delta i \alpha$, also called 'noonday demon,' is the most oppressive of all demons. He attacks the monk about the fourth hour and besieges his soul until the eighth hour ... [sending] him hatred against the place, against life itself, and against the work of his hands ... $" 17$

Both Evagrius and Cassian, in differing manners of emphasis, present the twofold effect of acedia as listlessness and restlessness. Cassian actually verbally conjoins both effects as a synonym for acedia: "somno otii vel acediae" ("by idle slumber or by acedia") (Institutes, X.21). In phenomenally rich language, Cassian describes acedia as a "weariness or distress of the heart"18 which is closely related to sorrow [tristitia $]^{19}$ and prevalent among those who live in solitude (Institutes, X.I). Cassian emphasizes the twofold impact that acedia can have on a monk:

And so the true Christian athlete ${ }^{20}$ who desires to strive lawfully in the lists of perfection, should hasten to expel this disease also from the recesses of his soul; and should strive against this most evil spirit of [acedia] in both directions, so that he may neither fall stricken through by the shaft of slumber, nor be driven out from the monastic cloister, even though under some pious excuse or pretext, and depart as a runaway.

\section{(Institutes, X.V)}

The vice of acedia typically produces one of two effects in its victim: either an overwhelming laziness or listlessness, or a restlessness that makes the monk want to abandon his post or simply to immerse himself in work other than the task at hand. Cassian notes that one can follow upon the other: "... those who will not work are always restless, owing to the fault of idleness" (Institutes, X.VIII).

The first effect, listlessness, can be captured in all sorts of rich, colorful behavioral description-idleness, laziness, slothfulness-but the actual underlying motus driving all these perceivable behaviors is a person's inner life, namely, the individual's will. Either the monk experiences velleity, a diminished exercise of the will, or abulia, a complete absence of any movement of will. The second effect, restlessness, is a kind of busyness, but should not be mistaken for productive busyness. It is characterized by a deep, inarticulable aversion to the meaningful, God-given, spiritually-imbued work of the cloister, in favor of other tasks that either are not as urgent, are not as important, or are simply not the task given to this individual monk. This latter effect of restlessness may thus actually result in activities that are "entertaining", or, as we would say in English, "diversions". ${ }^{21}$

Following Evagrius and other Egyptian monks, ${ }^{22}$ Cassian identifies the principal remedy for acedia as its opposing virtue, fortitudo (strength, courage) (Conferences, V.23). However, Cassian arguably places

17 Wenzel (1960, p. 5) quoting Evagrius of Pontus, Praktikos, 12. This translation appears to be Wenzel's own, based on

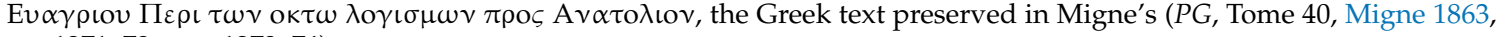
pp. 1271-78, esp. 1273-74).

18 "... quod Græci $\alpha \varkappa \eta \delta i \alpha v$ vocant, quam nos tædium sive anxietatem cordis possumus nuncupare."

19 It is unclear whether Cassian's Institutes were written originally in Greek or Latin (and one's answer to this will likely presuppose an answer to the question of who the real Cassian was). According to Migne's (PL, Tome 49, Migne 1846, pp. 9-11) historico-literary note which precedes Cassian's opera omnia, some Greek idiomatic phrases show up in Cassian's writings, making it possible that all of our extant copies are translations of original Greek manuscripts. Yet, while some books of the Institutes are preserved in Greek codices not older than the seventh century, the earliest printed edition was produced in Latin in Venice in 1481 (Tzamalikos 2012, p. 112, cf. 124). Tradition aligns Cassian with the Latin Fathers: note Migne's placement of his corpus in the series Latina rather than the series Græca.

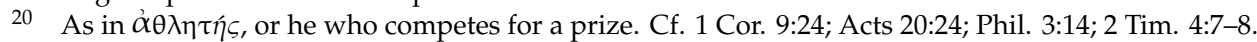

21 The Romance languages preserve this connection even more clearly: such as divertir (Fr., Sp., Pt.), from divertere (Lat.), which can mean variously "to divert/distract" or "to entertain"; as well as the derived adjectives divertente (It.) and divertissant (Fr.), which mean "entertaining", "funny", or "amusing".

22 Who had advised that the "main remedy against $\alpha \kappa \eta \delta i \alpha$ was to keep the cell, to practice endurance, to nourish supernatural hope, and so on" (Wenzel 1960, pp. 21-22). 
more point of emphasis than did previous writers on a second chief remedy: work by hand. For all the apparent tension between these two very different remedies, however, there is strong reason to conclude that the remedy for acedia with respect to one's inner life is to practice fortitudo, while the remedy for acedia with respect to one's outer life is manual work. ${ }^{23}$ Rather than meaningless activity, manual work is dignified when it has the proper end. Cassian's exhortations suggest that manual labor could be just as noble as brotherly love (1 Thess. 4:9), in that acedia (inquietudo, otiositas, anxietas sive taedium cordis) could be quieted and the heart made tranquil by a renewed, purposeful focus on meaningful work

From its beginning, acedia was designated as a capital vice, no doubt in part due to its twofold effect and its tendency to open the door to many other temptations. While Cassian was the first to establish a fixed progeny for each of the logismoi, ${ }^{24}$ Pope Gregory I (540-604) provides a memorable image, likening the capital vices to leaders of an army:

For the tempting vices ... some of them go first, like captains, others follow, after the manner of an army. For all faults do not occupy the heart with equal access ... For when pride, the queen of sins, has fully possessed a conquered heart, she surrenders it immediately to seven principal sins, as if to some of her generals, to lay it waste. And an army in truth follows these generals, because, doubtless, there spring up from them importunate hosts of sins.

(Moralia in Iob, 31.45.87)

In the case of acedia, we will find evidence of both tendencies-laziness and restlessness-among its "daughter" vices: "From [acedia] there arise malice, rancor, cowardice, despair, slothfulness in fulfilling the commands, and a wandering of the mind on unlawful objects" (Moralia in Iob, 31.45.88).

Finally, the Scholastics, principally St. Thomas Aquinas (1225-1274), round out the analysis by identifying the root of acedia qua sin, both its object and its cause. While the early Fathers like Cassian had included both tristitia (sadness) and acedia among the principal vices (their list had eight members), Aquinas lists only acedia among the Sins, while listing tristitia, properly speaking, only among the passions. But, ever the master of nuance, Aquinas assigns acedia (qua passion) as a species of tristitia. A person experiences tristitia when she perceives the conjoining of something bad to herself. ${ }^{25}$ The specific sorrow that is acedia characteristically occurs when, in sorrow, "the mind is weighed down so much, that even the limbs become motionless" (I.II.35.8.co). Like most passions tristitia is morally neutral when considered apart from a particular object or degree, ${ }^{26}$ yet tristitia becomes bad either when (a) a person, in her sorrow, misperceives a genuine good as evil [malum], or when (b) sorrow is immoderate, or ungoverned by reason. ${ }^{27}$ We see both happen in the specific case of acedia qua passion. In the first place, acedia goes awry when it manifests as "sorrow for spiritual good" (II.II.35), specifically, "sorrow about spiritual good in as

23 While Cassian "recommends cultivating fortitude and keeping the cell" in his Conferences, he goes through the whole Institutes "[speaking] only of manual work" (Wenzel 1960, p. 22, emphasis added). This tension is easily explained by examining Cassian's purpose for writing and the audience he had in mind for each work. "[T]he Collationes [Conferences] treats of the monk's 'inner dispositions,' whereas the Instituta [Institutes] is concerned with the external regulations given to a [cenobitic] monastic community in need of a rule" (Wenzel 1960, p. 22; cf. Conferences, Pt. I preface).

24 Since there is no model or analogue for such progenies in earlier writers, it is likely that Cassian's source for these progenies, in the case of acedia, derived from Paul's epistle to the Thessalonian church, commentary on which Cassian devotes roughly half of Book X (Institutes, X.7-16). The relevant passages are 1 Thess. 4:9-11 and 2 Thess. 3:6-15 An additional source might have been 1 Tim. 5:13, where we get the grouping "idlers, gossipers, and busybodies." Cf. Wenzel (1960, p. 21).

25 See Aquinas (1947), STh I.II.35-9. Crucially, acedia also is the name given to a species of tristitia, which, when taken in this sense of a passion, is not necessarily morally bad. Thomas discusses the two in two separate places in the Summa: acedia qua passion in I.II.35.8, and acedia qua sin in II.II.35.

26 We do not claim that all passions in themselves are morally neutral; rather, we purposely limit the claim to all passions at the level of genus considered apart from any object (to the extent this is possible). Cf. Miner (2009, p. 93) who says, "This Article [I.II.24.4] qualifies any simple view according to which Aquinas regards the passions as neither good nor evil in themselves." For example, "Envy is a passion that is evil in its species. Defined as sorrow for another's good, envy is evil per se. It is impossible to suffer envy toward the right person, at the right time, and in the right way."

27 "Wherefore sorrow, in itself, calls neither for praise nor for blame: whereas moderate sorrow for evil calls for praise, while sorrow for good, and again immoderate sorrow for evil, call for blame. It is in this sense that sloth [acedia] is said to be a sin" (II.II.35.1.ad1, emphasis added). 
much as it is a Divine good" (II.II.35.3). Thus, acedia undermines caritas (charity) ${ }^{28}$ by robbing a person of the joy which is its proper effect. Rather than experiencing joy, the person instead shrinks sorrowfully away from union with God precisely because she misconstrues this great good as a bad. In the second place, more simply, acedia goes awry when it manifests immoderately. ${ }^{29}$ Thomas is clear that even "a sorrow over what is genuinely bad is bad in its effect if it burdens [aggravet ${ }^{30}$ ] a man in such a way that it draws him back totally from good works [totaliter a bono opere retrahat]" (II.II.35.1.co). ${ }^{31}$ Clearly acedia's sluggish effects echo in this shrinking away from good works.

Aquinas goes on to give an insightful explanation of the daughter vices of acedia: "no one can remain for a long time without pleasure and with sadness, [hence] it is necessary for something to arise from the sadness" (ST II.II.35.4.ad2). ${ }^{32}$ Because a person cannot stay long in such sadness or active aversion, he either (a) withdraws from what's causing the sadness or (b) passes on to other things in which to take pleasure. The latter movement (b) is so uncomplicated that it be summarized in one daughter vice, a wandering of the mind on unlawful objects (evagatio mentis circa illicita). Thomas assigns the other five daughter vices to (a), indicating that there are various ways to characterize this withdrawing, whether by flight or fight. (i) Flight from man's spiritual end is despair (desperatio). Flight from the means to that end is either (ii) pusillanimity (shrinking from spiritual hardships that accompany the "counsels"), or (iii) listlessness (torpor) concerning the precepts (shrinking from fulfillment of the commands of justice in general, as with the Decalogue). "Such flight", Wenzel puts it, "sometimes leads to a sort of inner fighting against the causes of aversion."33 (iv) Rancor is characterized by fighting against those persons who embody spiritual goods; (v) whereas malice (malitia) is that same inner battle against the spiritual goods themselves. Regardless of which daughter vice obtains, it obtains fundamentally as a result of that sadness, or aversion to, the Divine good.

From this discussion, we can summarize the traditional view of acedia in the following way: it is a sorrow over or a being weighed down away from divine good, in a way that is contrary to the rest that one ought to find in God. Its twofold effect is improper rest (listlessness, idleness) and restlessness. Fundamentally, its remedy consists in proper rest in God and His Goodness. To that end, acedia's principal remedy, fortitudo, serves to strengthen the inner life through weariness and struggle, whereas its secondary remedy, manual work, can lead one to inner quietude. Aquinas's examination of its object and cause, along with his eudaimonistic framework that emphasizes man's proper end, union with God, reinforces the idea that work is dignified, especially when it is done in light of one's vocation given by God. Aquinas's account is also helpful is revealing how subtly acedia-a surreptitious logismos from its beginning — can creep from passive affect to outright willful sin. Importantly, though not obvious given its monastic origins, acedia is not unique to monks: from Cassian onward, knowledge of

28 Aquinas defines charity as "a certain friendship of man with God, founded upon a sharing of eternal blessedness. Now this sharing is not according to natural goods, but rather according to gifts freely given ... So charity can neither be in us naturally, nor by natural powers that are acquired, but only by an infusion of the Holy Spirit, who is the love of the Father and the Son, whose participation in us is created charity itself" (II.II.24.2).

29 Interestingly, (b) concerns not the object but the mode of sorrow, that is, the way in which it manifests, moderately or immoderately. And while the moderation of sorrow is done by reason, this error is different from (a), which seems to be more properly an error of reason, since it is misidentifying the good object as bad. These both, however, seem to come in degrees (How bad? How immoderate?), which makes it difficult to say how vicious any instance of acedia is (thus our use of "goes awry" as opposed to "becomes vicious"); and whether this degree of badness tracks with the distinction between acedia qua passion that is bad per se because of its object (cf. Miner 2009, p. 93), and acedia qua capital sin. (It is not clear when one becomes the other, but that may be an inherent issue of vagueness.) Perhaps Thomas's discussion of venial and mortal sin with respect to acedia may be of help here (II.II.35.3.co).

30 Meaning "weighed down." Thomas speaks generally of sorrow as metaphorically "weighing down" (I.II.37.2.co), but also two species of tristitia in particular: anxietas / angustia (I.II.35.8.arg3), and acedia (I.II.35.8.co).

31 This implies that a moderate acedia (qua passion) can be morally good, namely, when the object of moderate acedia is an evil. And a certain reading of Thomas seems to confirm this (cf. II.II.35.1.ad1).

32 Recall, sadness is fundamentally aversion to anything that presents as evil; in this case, by "the sadness" Thomas is referring to acedia, "a very special kind of such a negative reaction of the appetite ... very intimately linked to the deepest roots of man's affective and volitive life" (Wenzel 1960, p. 55).

33 (Wenzel 1960, p. 51). 
acedia steadily spread outward from the cloister into the wider world, where it became recognized as a common affliction among all men. ${ }^{34}$ With this in mind, we will turn to Kierkegaard's work to see how his writings help to extend and develop the concept of acedia as it manifests in the individual, from the religious to the aesthete.

\section{Extending the Tradition: Acedia in Either/Or}

In keeping with our thesis, our examination of Either/Or reveals the following themes. First, Kierkegaard is no doubt familiar with the Christian capital vices tradition. More than this, in Either/Or, one can see from him a natural extension and development of this tradition with the presentation of different perspectives of acedia. It should go without saying that a full perspectival analysis of acedia does not appear at once in this or any single work. ${ }^{35}$ Thus, the perspectives we see in Either/Or are limited to the following: of the firsthand experience of acedia from the aesthetic life (or, "aesthetic acedia") (Vol. I), and that of the diagnosis or evaluation of aesthetic acedia as seen from both the aesthetic sphere (Vol. I) and the ethical sphere (Vol. II).

Although we shall examine them individually in what follows, Volumes I and II of Either/Or should be considered as a whole. ${ }^{36}$ Whereas Vol. I contains a collection of writings and correspondence from an unnamed aesthete who is referred to only as "A", Vol. II contains the letters to A from Judge Wilhelm. ${ }^{37}$ Both characters are creations of Søren Kierkegaard, who, of course, is the author of both volumes. In considering both volumes of Either/Or as of one piece, we can see more clearly the continuity in Kierkegaard's own thinking, including, but not limited to, his understanding of acedia.

\subsection{Volume I}

Through his discussion of his own state and reflection on how to deal with it, A the aesthete presents us with a distinctively aesthetic acedia. Despite obvious differences, there are deeper similarities between A's self-reported aesthetic acedia and the Christian tradition's descriptions of acedia that come into relief especially when we read the texts alongside one another. ${ }^{38}$ For example, in EO I near the beginning of the so-called Diapsalmata, ${ }^{39}$ A starkly reports an experience of something like acedia (though he presumably does not know it by that name ${ }^{40}$ ):

I don't feel like doing anything. I don't feel like riding-the motion is too powerful; I don't feel like walking - it is too tiring; I don't feel like lying down, for either I would have to stay down, and I don't feel like doing that, or I would have to get up again, and I don't feel like doing that, either. Summa Summarum: I don't feel like doing anything.

$(E O \mathrm{I}, 20)^{41}$

34 As Harmless (2004, p. 373) puts it, “Cassian, more than anyone else, brought Egypt to the West.” Cf. Wenzel (1960, pp. 18-23ff.) and Bloomfield (1952, pp. 69-74ff.).

35 In addition, there are certain familiar (albeit partial) aspects or elements of the traditional concept of acedia emphasized here in this work that may or may not be emphasized in Kierkegaard's other works. Specific to Either/Or, for instance, we see special attention paid to the twofold effects of acedia: laziness/listlessness and restlessness/busyness, especially as it relates to one's occupation and aversion to work, yet not explicitly how this work relates to God or divinely given vocation.

36 We use the Hong edition for both volumes. In text we cite volumes I and II as EO I and EO II, respectively. (Kierkegaard 1987a, 1987b).

37 On the one hand, it is not clear how much of A's writings are actually known to Wilhelm, and so these letters are not necessarily meant to be understood as replies. On the other hand, Kierkegaard is the origin behind both pseudonyms, so it is not unreasonable to think they are fashioned as a dialectic. Indeed, Kierkegaard removes himself even more by employing a further pseudonym, Victor Eremita, as editor of the whole work, a move which apparently provoked much consternation-cf. (McCarthy 1978, pp. 56-57).

38 For longer discussions of these parallels, see (Podmore 2011, pp. 50-67; Pattison 2013; McDonald 2009).

39 Or scraps of paper written by A, which the editor tells us "could best be regarded as preliminary glimpses into what the longer pieces develop more coherently" (1987a, EO I, 8). Diapsalmata is related to "psalm", a term roughly meaning "refrain"; it is an overt allusion to Marcus Aurelius' Meditations. Cf. Furtak (2009, pp. 71-72).

40 As we see later, Judge Wilhelm expressly identifies A's condition as acedia.

41 This passage is taken from a longer journal entry which Kierkegaard himself wrote in 1837 (JP (SKS/ KJN) V 5251; Pap. II A 637), which suggests that he may have been wrestling with this very phenomenon. Kierkegaard reveals in a separate journal 
In addition to this vivid description, A alternates (both here in the Diapsalmata and in various later sections) between a few select terms to describe his phenomenal state: Tungsind ("heavy-mindedness"; "melancholy"), ${ }^{42}$ Sorg ("sorrow"; "sadness"), ${ }^{43}$ and Kjedsommelighed ("boredom"; "tediousness"; "weariness"). ${ }^{44}$ The term Tungsind has no direct English equivalent, ${ }^{45}$ so we leave it untranslated from here onward whenever possible. ${ }^{46}$ It should be noted that "boredom" as used here conveys a deeply existential, spiritual, or psychological state. The Hongs translate Kierkegaard's choice of Kjedsommelighed in EO to the English "boredom", but it seems that Kierkegaard had in mind something much more robust than the usual connotation of "boredom". Instead of using the words Kjedsomhed ("boredom") or kjedelig ("boring"), which are found elsewhere in his authorship, ${ }^{47}$ Kierkegaard seems to have actually combined these together into Kjedsommelighed ("boring-boredom" ${ }^{48}$ ) in order to underscore the way it deeply permeates the soul.

A close reading of "The Rotation of Crops" in light of the traditional, monastic advice for dealing with acedia reveals not only Kierkegaard's familiarity with the tradition, but also what is distinctive about aesthetic acedia. To mention just a few similarities here, in The Institutes, Cassian had cautioned the brothers against idleness through a reading of St. Paul's letters, counseling that acedia is thus fought by manual labor (especially), perseverance, and staying in one's place [stabilitas loci]. Each of these three pieces of advice on resisting acedia can be seen in "The Rotation of Crops." This is all we shall say for now about aesthetic acedia according to the phenomenal axis, as we turn next to the evaluative axis. $^{49}$

Taking up more space in EO I is the second axis, the diagnosis or evaluation of aesthetic acedia, specifically from the aesthetic perspective. This includes A's judgment about what his condition is, how to understand it, and ultimately how he proposes to remedy it. This is most clearly seen in the section "The Rotation of Crops," named after the method A devises for dealing with this aesthetic acedia he calls boredom [Kjedsommelighed].

To begin with, A states simply "all people are boring [kjedsommelige]" (EO I, 285). "Boredom [Kjedsommelighed] is the root of all evil" (EO I, 285), and therefore operates as a negative or repelling

entry (JP (SKS/ KJN) V 5631; Pap. IV A 221) that even more of his own "aphorisms ... could have been used very well." Cf. the Hongs' historical introduction in EO I, ix.

42 "In addition to my other numerous acquaintances, I have one more intimate confidant-my depression [Tungsind]. In the midst of my joy, in the midst of my work, he beckons to me, calls me aside, even though physically I remain on the spot. My depression [Tungsind] is the most faithful mistress I have known—no wonder, then, that I return the love" (EO I, 20). "Wine no longer cheers my heart; a little of it makes me sad-much, depressed [tungsindig]" (EO I, 41).

43 "I say of my sorrow [Sorg] what the Englishman says of his house: my sorrow is my castle" (EO I, 21).

44 "How dreadful boredom [Kjedsommelighed] is-how dreadfully boring; I know no stronger expression, no truer one, for like is recognized only by like. Would that there were a loftier, stronger expression, for then there would still be one movement. I lie prostrate, inert; the only thing I see is emptiness, the only thing I live on is emptiness, the only thing I move on is emptiness. I do not even suffer pain" (EO I, 37).

45 Cappelørn (2008) points out terms that are nearby, himself preferring "spleen": "The German terms Schwermut and Weltschmertz, the French term ennui, and the English terms "Byronism" and "spleen" are all designations for the world-weariness, aestheticism, and loss of values that were common themes for European romantic writers. And it is in this group of terms that the Danish Tungsind belongs" (p. 133).

46 On this score, Cappelørn (2008) writes, "if it is a cultural-linguistic fact that no English word is fully equivalent to Tungsind, Hannay's 'melancholy' is nonetheless clearly preferable to the Hongs' 'depression'” (p. 132). Cappelørn himself ultimately prefers "spleen" to either of these. We avoid using the Hongs' translation of Tungsind as "depression", in part, because of the misleading modern-day connotations associated with that word. And we do not follow Cappelørn all the way in rendering the term as "spleen" because we simply do not use that word in that sense today. For reservations on using "melancholy", see (Cappelørn 2008, pp. 132-33).

47 In both volumes of EO in particular, according to Søren Kierkegaards Skrifter (www.sks.dk), "Kjedsommelighed" appears eighteen times, "Kjedsomhed" zero times, and "kjedelig" twice. In fact, "Kjedsomhed" appears only twice in Kierkegaard's published writings, once in his unpublished writings, and once in his journals.

48 Or perhaps "boring-ness", as suggested by Marilyn Piety (p.c.). Each of the three Danish words begins with the root "K(j)ed" and are constructed, in the usual compounding manner of Germanic languages, using various of the following suffixes: "-som" = "-some" (characterized by some specific condition or quality); "-(m)el" = "-al"; "-ig" = "ongoing" as in "-y" (n. to adj.); "-hed" = "-ness" (adj. to abstract n.).

49 There is of course more one can say about A's firsthand description of aesthetic acedia, and we shall say more, but in conjunction with later material. 
first principle of action that is "not merely repelling but infinitely repulsive" (EO I, 285). Contrary to received wisdom, then, idleness itself is not the root cause of one's troubles:

Idleness, we are accustomed to say, is the root of all evil. To prevent this evil, work is recommended. But... Idleness as such is by no means a root of evil; on the contrary, it is a truly divine life, if one is not bored. To be sure, idleness may be the occasion of losing one's property, etc., but the noble nature does not fear such things but does indeed fear being bored. The Olympian gods were not bored; happy they lived in happy idleness.

(EO I, 289)

If man's purpose is to work, A argues, then the idleness/work antithesis would be correct; but assuming, as A does, that "man's destiny is to amuse himself," the correct antithesis is actually rather boredom/amusement (EO I, 290). Put another way, while idleness can be canceled by work, boredom cannot, for work and boredom are not opposed, "as is seen in the fact that the busiest workers of all, those whirring insects with their bustling buzzing, are the most boring of all ..." (EO I, 290). We should therefore attempt to cancel not idleness, but boredom, by engaging in its opposite, amusement.

So far, A's evaluation of and remedy for aesthetic acedia in some ways runs counter to the Christian tradition regarding acedia. For instance, the tradition would not recommend amusement itself as a remedy. While the tradition does recommend work and manual labor, something A adamantly thinks fails, it does not recommend it solely. Importantly, that labor must be imbued with special vocational meaning, an element that, when included with work, would more likely keep boredom at bay. Perhaps this added element of meaning and worthwhileness is what A is really after in his remedy, so we must read on.

Next, A discusses two rival ways to implement amusement as a solution to boredom: what individuals ordinarily do, and his own proposal. Indeed, "All who are bored cry out for change" (EO I, 291), ${ }^{50}$ but most people get it wrong when they try to fix it. This first attempt A calls "vulgar," "inartistic," and "based on an illusion" (EO I, 291). The ordinary bored man often simply tries "changing the soil," that is, changing his external circumstances (e.g., moving to the city, eating with new cutlery, etc.) (EO I, 291-92), or else by engaging in work characterized by "indefatigable activity" merely to avoid his boredom (EO I, 289). Even a remedy this vulgar has some perceivable effect. It can awaken the will from the velleity or abulia that we see in acedia's first effect, listlessness, but this remedy is not lasting, since such temporary diversions cannot sustain amusement. Moreover, as A recognizes correctly, work simply qua indefatigable activity "shuts a person out of the world of spirit and places him in a class with the animals, which instinctively must always be in motion" (EO I, 289). This of course calls to mind acedia's second effect, restlessness (e.g., an urge to leave one's cell, to depart the cloister, etc.). Trading one effect of acedia for another, it is not surprising that this method fails to cancel boredom.

In contrast to the ordinary method of "continually changing the soil" (EO I, 291), A's own proposal, "like proper crop rotation, consists in changing the method of cultivation and the kind of crops" (EO I, 292). In this way, one practices stability of place and stays with the same soil. Such limitation is crucial to the method and "the sole saving principle in the world," forcing one to be resourceful in being amused (EO I, 292). The key insight of this method is that one must change oneself instead of one's surroundings in order to avoid boredom: "one ought to develop not so much extensively as intensively" (EO I, 298).

A offers three strategies for cultivating oneself so as to achieve amusement: forgetfulness, guarding against social relations, and arbitrariness. Fundamental towards achieving these three is a prior principle: "it is essential to have control over one's moods" (EO I, 298). Perseverance and calm

50 "Forandring raaber Alle, der kjede sig, paa." 
deliberation are necessary for resourcefully and creatively cultivating amusement, lest one falls into further boredom (EO I, 291). The first strategy for guaranteeing amusement, one must become skilled in forgetfulness:

To forget-this is the desire of all people, and when they encounter something unpleasant, they always say: If only I could forget! But to forget is an art that must be practiced in advance. To be able to forget always depends upon how one remembers, but how one remembers depends upon how one experiences actuality.

(EO I, 293)

If we are used to experiencing things too vividly in either direction, good or bad, then we will be unable to forget. So, we must dampen the vividness of our positive experiences-"nil admari [marvel at nothing] is the proper wisdom of life" (EO I, 293) - by being judicious about how we enjoy. We must only enjoy in a way that allows us to recollect, or not, on our own terms. This requires practicing a mistrust of experience and distancing ourselves from actuality so that even "when in the midst of enjoyment one looks at it in order to recollect it" (EO I, 294). "When an individual has perfected himself in the art of forgetting and in the art of recollecting in this way, he is then able to play shuttlecock with all existence" (EO I, 293).

The second strategy for guaranteeing amusement, one must guard against friendships, relations, and other "superfluous thirds" (EO I, 295), ever tempering one's own expectations of happiness from others, and imbuing the insignificant with significance. A advises staying clear of the commitments of friendship (EO I, 295-96), marriage (EO I, 296-98), and official posts (EO I, 298). ${ }^{51}$ But importantly, "Even though one stays clear of official posts, one should nevertheless not be inactive but attach great importance to all the pursuits that are compatible with aimlessness; all kinds of unprofitable pursuits may be carried on" (EO I, 298). ${ }^{52}$ Indeed, "It doesn't take much to amuse a child" (EO I, 298). A thinks we ought still to vary the soil, or external circumstances; just as a farmer has many acres and must let some lie fallow at times, so we must have some variety of life experiences. But more crucial is learning to use one's moods (perhaps an analogue to the different types of crops) with the right soil at the right time: "one must continually vary oneself, and this is the real secret" (EO I, 298). To this end, one must have control over one's moods to the degree possible, which involves recognizing the signs of a mood arising and its effect on oneself and others. Such self-control and understanding will also allow one to provoke others to amusement by influencing their moods-e.g., making a boring, sentimental person amusing by making them peevish through teasing (EO I, 299).

The final strategy for guaranteeing amusement, as A explains: "Arbitrariness is the whole secret" (EO I, 299). Together with the ability to forget and to vary oneself, the agronomist of amusements can avoid boredom in any situation, by leveraging arbitrariness. "It is popularly believed that there is no art to being arbitrary, and yet it takes profound study to be arbitrary in such a way that a person does not himself run wild in it but from himself has pleasure from it" (EO I, 299). A recounts an example of an acquaintance who was prone to boring philosophical lectures during conversations. Upon discovering that he could follow the man's perspiration from its beginning on his forehead to its hanging off of the man's nose, A was amused by the man instead of bored. To practice arbitrariness, "something accidental must be made into the absolute and as such into an object of absolute admiration" (EO I, 299-300). Here, one's ability to play shuttlecock with existence releases oneself from being caught up in what is actually happening so that one can notice amusing, incidental features. Further, one's ability

51 "It may be thought that such conduct leaves unpleasant recollections, that the unpleasantness consists in the diminishing of a relationship from having been something to being nothing. This, however, is a misunderstanding. The unpleasantness is indeed a piquant ingredient in the perverseness of life. Moreover, the same relationship can regain significance in another way" (EO I, 296).

52 While this seems to contradict A's previous tip, it seems nevertheless true that one's attaching great importance to something otherwise insignificant does not entail that one's experience of that thing would be vivid. 
to vary oneself helps one be ready to be entertained by the amusements available. "The accidental outside of a person corresponds to the arbitrariness within him. Therefore, he always ought to have his eyes open for the accidental, always to be expeditus [ready] if something should come up" (EO I, 300).

Thus ends A's own aesthetic evaluation of aesthetic acedia. Before we turn to the Judge's ethical evaluation of aesthetic acedia, let us see how A's account fares next to the Christian tradition. First, A certainly supplies the aesthete with a rule of life for pursuing good (i.e., amusement) and avoiding evil (i.e., boredom) ${ }^{53}$ but similarities fade beyond this. Unlike the Desert Fathers, the aesthete recognizes no higher good than amusement, and boredom is not an expression of something deeper going wrong; it itself is the greatest evil and must be avoided. This of course runs counter to Christian monastic and Scholastic accounts of acedia, which takes God and loving him as the highest good, and separation from God as the greatest evil.

Second, A correctly identifies boredom as a powerful kind of repelling force, reminiscent of the desert monk restlessly pacing the halls, avoiding work. A also rightly recognizes, like Evagrius and Cassian, that boredom will not be defeated merely by indefatigable activity, movement, work, or escape. Instead, one must remain where he is and persevere with calm deliberation. To this extent, A's theory reflects an improvement over merely "changing the soil," or one's external circumstances. But while this strategy seems to address both of acedia's effects, listlessness and restlessness, it will not do to remedy acedia sufficiently if the Christian tradition is correct about acedia reflecting a deeper spiritual problem. ${ }^{54}$ To recall A's words, to ignore this aspect is, in some sense, to "shut a person out of the world of spirit" (EO I, 289).

Third, there appears to be some similarity in how both A and the Christian tradition recognize that a calling beyond oneself-whether it be sanctification, special vocation, friendship, marriage, or official post-is a contributor to acedia. Reflecting closely upon this similarity and others, such as their common recognition of being tied to something causing boredom, paradoxically illuminates for us just how different the two views really are. For A, all people are boring; it is a universal problem regardless of station, whereas the Christian tradition considers it a religious problem, which, though universal, is grounded in one's God-given vocation. A greater disparity, however, lies in the direction to which the advisor points. A points the aesthete away from these external, higher callings; the Christian tradition ushers him towards it. A's suggestions aim only at stirring up amusement and minimizing or avoiding ubiquitous boredom; the Christian tradition advises leaning into the boredom, with proper end in sight, so it is transformed as no longer boring. And it is here where we see the two fully come apart, because it matters infinitely what the individual is ushered towards. For this, we must mature beyond the aesthetic sphere, beginning naturally with what someone in the ethical sphere would say about aesthetic acedia.

\subsection{Volume II}

The second volume of Either/Or contains the letters that Judge Wilhelm wrote to A. The Judge argues that for any individual there is an unavoidable either/or choice between the aesthetic life and the ethical life.

But what does it mean to live [a]esthetically, and what does it mean to live ethically? What is the [a]esthetic in a person, and what is the ethical? To that I would respond: the [a]esthetic in a person is that by which he spontaneously and immediately is what he is; the ethical is that by which he becomes what he becomes.

(EO II, 178)

53 As Harries (2010) points out, "the polarity of the interesting and the boring replaces the traditional polarity of good and evil; similarly, it replaces the traditional polarity of beauty and ugliness" (p. 98).

54 But of course, rather than contraindicate the Christian tradition, this only reaffirms it. Since the Christian tradition predicts that the aesthete, unconcerned with the things of heaven, will not consider spiritual solutions. 
A's problem, the Judge explains, is that he is stuck in a kind of immediacy. The aesthete cannot provide a proper account of the aesthetic life because he is trapped in the moment and "can in a higher sense explain nothing" (EO II, 179).

To understand the Judge's analysis of aesthetic acedia, we must understand the five important stages that constitute the aesthetic life. We only briefly review the first three stages, while the last two stages will be key for understanding the distinctiveness of an ethical analysis of acedia. Recall, as even A noted, that all aesthetic individuals assume a life-view (i.e., "a conception of the meaning of life and of its purpose") that revolves around the idea that life is meant to be enjoyed (EO II, 179). These individuals are distinguished by whatever condition they use to measure their enjoyment. ${ }^{55}$ In Stage 1, the condition is immediately qualified physically; enjoyment is defined in terms of physical conditions like health and beauty. In Stage 2, the condition is now placed outside the individual in something like wealth, honors, or falling in love. With Stage 3, the condition is internal to the individual, but she is not responsible for it in any way. For example, enjoyment is found in exercising one's talents.

Before considering the fourth stage, Wilhelm points out how the first three stages have a kind of unity and coherence. Whether it be one's beauty, wealth, or talent, each of these stages revolves around a single thing. "What they build their lives upon is something simple, and therefore this life-view is not fragmented as is the life-view of those who build upon something intrinsically multiple" (EO II, 183). Such is the next stage, which Wilhelm notes he will dwell on a bit longer. For our purposes, we note the motion of the stages is already moving the aesthete away from having a unified personality; this, we think, demonstrates the intrinsic tendency for the aesthetic life-view to disperse and fragment, which only accelerates in the final stages.

In Stage 4, the idea that life is meant to be enjoyed is interpreted as "Live for your desire" (EO II, 183). Here the condition seems to be internal, but numerous external conditions (e.g., having enough money) must be in place for one to carry out this life-view. The Judge mentions the emperor Nero as a particular example of someone at this stage. ${ }^{56}$ He claims that Nero's nature was essentially constituted by Tungsind. This is not the genius melancholy that $\mathrm{A}$ is familiar with.

Nero's nature was [Tungsind]. In our day, it has become somewhat prestigious to be [tungsindig]; as far as that goes, I can well understand that you find this word too lenient; I hold to an ancient doctrine of the Church that classifies [Tungsind] among the cardinal sins.

(EO II, 185)

Again, Kierkegaard displays his familiarity with the capital vices tradition. In fact, in a journal entry from 1839, he discusses it explicitly, mentioning both acedia and tristitia by name. ${ }^{57}$ While this entry establishes Kierkegaard's own familiarity, along with a special interest in both of these vices; it is unclear, from Wilhelm's comments alone, whether Wilhelm is referring to acedia or tristitia. ${ }^{58}$ To gain clarity on this issue, we will need to pay close attention to Wilhelm's portrait of Nero.

55 "But the person who says that he wants to enjoy life always posits a condition that either lies outside the individual or is within the individual in such a way that it is not there by virtue of the individual himself. I beg you to keep rather fixed the phrases of this last sentence, for they have been carefully chosen" (1987b, EO II, 179; italics in original).

56 For an in-depth and insightful discussion of this passage, see Cappelørn (2008).

57 "What in a certain sense is called "spleen" and what the mystics knew by the designation "the arid moments," the Middle Ages knew as acedia ( $\alpha \chi \eta \delta \iota \alpha$, aridity). Gregoria, Moralia in Job, XIII, 435: Virum solitarium ubique comitatur acedia .... . est animi remissio, mentis enervation, neglectus religiosae exercitationis, odium professionis, laudatrix rerum secularium. [Wherever aridity encompasses a solitary man ....... there is a lowering of the spirit, a weakening of the mind, a neglect of religious practice, a hatred of profession, a praise of secular things.] That Gregory should emphasize virum solitarium points to experience, since it is a sickness to which the isolated person [is exposed] at his highest pinnacle (the humorous), and the sickness is most accurately described and rightly emphasized as odium professionis and if we consider this symptom in a somewhat ordinary sense (not in the sense of churchly confession of sins, by which we would have to include the indifferent church member as solitarius) of self-expression, experience will not leave us in the lurch if examples are required. 20 July 1839. The ancient moralists show a deep insight into human nature in regarding tristitia among the septem vitia principalia." (JP $(S K S / K J N)$ I 739).

58 Not to mention, the journal entry was written during Kierkegaard's doctoral studies over two years prior to the publication of Either/Or. 
The Judge describes Nero as having enjoyed a vast variety of pleasures throughout his life, but as he grows older he begins to require new and diverse pleasures, "because only in the moment of pleasure does he find rest" (EO II, 186). Yet as soon as the moment of pleasure is over, Nero "yawns in sluggishness" (EO II, 186), suggesting that, rather than a true rest in God, it is rather a misplaced rest which the early Fathers had associated with acedia. Eventually, Nero loses even this ability to rest in pleasures, his soul overcome with "an anxiety that does not cease even in the moment of enjoyment" (EO II, 186), a state reminiscent of acedia's second effect, restlessness. Wilhelm locates the source of Nero's Tungsind in his being "immediate spirit" which is "ripe for immediacy" yet which fails to lay hold of immediacy:

What, then, is [Tungsind]? It is hysteria of the spirit. There comes a moment in a person's life when immediacy is ripe, so to speak, and when the spirit requires a higher form, when it wants to lay hold of itself as spirit. As immediate spirit, a person is bound up with all the earthly life, and now spirit wants to gather itself together out of this dispersion, so to speak, and to transfigure itself in itself; the personality wants to become conscious in its eternal validity. If this does not happen, if the movement is halted, if it is repressed, then [Tungsindet] sets in.

(EO II, 188-89)

Nero, for his part, had at some point come to the realization that life is more than immediate pleasure and gratification, but he ultimately dismissed this and returned to his life of immediacy. This rejection underscores Wilhelm's adamancy that Tungsind is not merely a mood that one falls into, but is a sin;" "it is the sin of not willing deeply and inwardly, and this is a mother of all sins" (EO II, 189). Now, rather than despair of his judgment, the Judge encourages the aesthete to look on the bright side. ${ }^{60}$ Melancholy can be beneficial if it teaches a person "to bow in true humility before the eternal power" (EO II, 189). In fact, this very movement of submission-which the Judge goes on to call "repentance" (EO II, 216)—is the only true remedy for Tungsind (EO II, 189).

Finally, the Judge finally turns to Stage 5, which he calls "despair itself" (EO II, 194). Wilhelm had previously noted that all the aesthetic stages are disguised forms of despair, ${ }^{61}$ but he also thinks that despair itself is a stage of its own, and that A inhabits this stage. According to Wilhelm, despair is the recognition that one's very life and pursuits are meaningless and vain. Here we see a direct parallel with the Christian tradition, which held that despair was one of the daughter vices of acedia. ${ }^{62}$ While despair is indeed vicious, the Judge once again points out a redeeming element: despair, like Tungsind, can lead one to repentance.

Thus concludes Wilhelm's ethical analysis both of aesthetic acedia as a whole and of A's more reflective aesthetic attempt, in his theory of crop rotation, to cancel aesthetic acedia. Taking Stage 4 and 5 together, it is now clearer that Wilhelm was indeed talking about acedia. Of course, the major addition at Stage 4 is the external condition: the very enjoyment the aesthete longs for is transcendent. Indeed, the

59 Pieper (Pieper 1986) notes this when he discusses despair, a kind of which (despair of weakness) Pieper argues is acedia. "Today when we speak of despair we are usually referring to a psychological state into which an individual 'falls' almost against his will. As it is here used, however, the term describes a decision of the will. Not a mood, but an act of the intellect. Hence not something into which one falls, but something one posits. The despair of which we are speaking is a sin. A sin, moreover, that bears the mark of special gravity and of an intensity of evil."

60 "But the person who wants to be eminently endowed will have to tolerate my placing the responsibility upon him and his capacity to be more at fault than other people. If he looks at this in the proper light, he will not see this to be a disparaging of his personality, even though it will teach him to bow in true humility before the eternal power" (EO II, 189).

61 "Consequently, it is manifest that every [a]esthetic view of life is despair, and that everyone who lives [a]esthetically is in despair, whether he knows it or not" (EO II, 192).

62 See Gregory (1844, Moralia in Iob, 31.45.88) and Aquinas (1947, STh II.II.35.4). In fact, Thomas's view seems to imply that despair occupies a central place among the daughter vices of acedia, given that despair is associated with the avoidance of the end (the divine good) rather than with the avoidance of certain means to that end (e.g., precepts and counsel-whose associated daughter vices would be listlessness and pusillanimity, respectively). 
aesthete at these stages has become more reflective and has progressed a bit more towards the ethical sphere. The aesthete recognizes that his desires aim outwards, but still they are not satisfied. The Judge seems to think that it is simply the failure to obtain this transcendent immediacy, without which the "immediate spirit" which is "ripe for immediacy" sloughs into sullenness as Tungsind sets in. While the Christian tradition would agree, the key absence here is the proper object, the proper good, which is God. It is insufficient, as the Judge recommends, to repent before an unnamed, presumably impersonal "eternal power" - where is the joy in that? If Aquinas is indeed correct that caritas engenders joy, it is hard to see how joy, let alone caritas itself (i.e., love of and friendship with God), has a place here. With this absence, this ethical analysis of aesthetic acedia proves to be incomplete.

In sum, Either/Or presents us with a clear portrait of aesthetic acedia, both from the aesthetic (Vol. I) and the ethical perspective (Vol. II). There is some temptation to infer, from Judge Wilhelm's own claims, what an ethical acedia might look like, but we caution against this since Wilhelm is not expressly concerned with evaluating the ethical sphere. For that we turn to another work, The Sickness Unto Death.

\section{Synthesizing the Tradition: Acedia in The Sickness Unto Death ${ }^{63}$}

Having expanded upon the traditional account of acedia to include its aesthetic manifestation in Either/Or (1843), Kierkegaard provides through his concept of despair in The Sickness Unto Death (1849) a more comprehensive and thoroughgoing analysis of all the different manifestations of acedia: from the aesthetic, to the ethical, to the religious spheres. The boundary cases are easier to identify-aesthetic acedia in the lowest form, unconscious despair, and religious acedia in the highest form, defiant (and demonic) despair-but the manifestations in between will require a more nuanced explication. As for the two axes, we try to stay faithful to Anti-Climacus' own exposition: there are moments when he devotes more to describing than evaluating, and vice versa, so the sections below reflect this imbalance.

For Anti-Climacus, ${ }^{64}$ despair fundamentally arises as the result of a mis-relation in the elements of the self or in the self's relation to God (SUD 15). ${ }^{65}$ Hence, a self which is not in despair is appropriately related both internally (within the self) and externally (to God). Anti-Climacus explains that despair is thus $\sin$ (SUD Pt. II) and only by its removal can a person become a fully integrated self, ${ }^{66}$ wherein "the self rests transparently in the power that established it" (SUD 14). Later on, Anti-Climacus identifies this state as the state of faith (SUD 82).

Although Anti-Climacus considers despair both objectively and subjectively, we, for want of space, track here with the latter, of which there are three main forms. ${ }^{67}$ First, there is unconscious despair: despair that is ignorant of being in despair. By far the most common form, those who suffer from this type have a mis-relation in the self yet are unaware of it. Beyond this, despair is conscious, where we find the second and third types of despair, distinguished respectively by the way in which

63 We cite the Hong edition (Kierkegaard 1980) as SUD.

64 Kierkegaard describes Anti-Climacus in his journals as being a "Christian on an extraordinarily high level" (JP(SKS/ KJN) VI 6433). Kierkegaard chose the pseudonym because he did not feel qualified to deliver its message. In a certain sense, Kierkegaard wanted to place himself under the judgment of the book, along with other readers.

65 In fact, Anti-Climacus begins his explication of the various forms of despair by exploring the crucial aspects of the self that must be related. He claims that the human self is a synthesis in two important dimensions: finitude/infinitude and possibility/necessity. Any time that one of these qualities is emphasized to the exclusion of its opposite, the self will find itself in despair.

66 Present in the very word despair ["Fortvivlelse"] is the notion of a natural unity being split into two ["tvi"], the self apart from God, which entails the self being split apart from oneself.

67 Anti-Climacus has two ways of explicating the different forms of despair: according to the "constituents of the synthesis" (pp. 29-42) [see fn. 44] — what can be termed the objective — and according to the level of consciousness of the person in despair (42-74) - what can be termed the subjective. These are not mutually exclusive, but are simply two ways of analyzing what is the same thing. Our discussion prioritizes the latter, since Anti-Climacus devotes more time to it and the parallels with acedia are more visible. 
the self responds to its despairing condition: the despair of weakness occurs when the self in despair does not will to be oneself, whereas defiant despair occurs when the self in despair wills to be oneself.

\subsection{Unconscious Despair: Despair That Is Ignorant of Being Despair}

The form most unlike what we normally call "despair" is also the most common form of despair. ${ }^{68}$ Anti-Climacus describes those who suffer from this type of despair as being ignorant of "having a self and an eternal self" (SUD 42). "Such a despair, in comparison with more active, defiant forms, almost possesses a kind of innocence. Here the problem with the person is simply that she does not understand that she was created to be spirit." ${ }^{69}$ Usually this person will even tend to become angry when others attempt to enlighten him about the self he could become. Anti-Climacus explains: "Because he is completely dominated by the sensate and the sensate-psychical, because he lives in sensate categories, the pleasant and the unpleasant, waves goodbye to spirit, truth, etc., because he is too sensate to have the courage to venture out and to endure being spirit" (SUD 43). Asking the reader to imagine the self as a multi-level house, Anti-Climacus compares this person to one who lives only in the basement: "Every human being is a psychical-physical synthesis intended to be spirit; this is the building, but he prefers to live only in the basement, that is, in sensate categories" (SUD 43). Clearly, Anti-Climacus is describing the aesthete (SUD 45) who, caught in immediacy, is ignorant of having a self-let alone an eternal self.

The parallels to aesthetic acedia as illustrated and analyzed in Either/Or are obvious. Acedia's twofold effect of listlessness and restlessness is prominent-as when Anti-Climacus points out the many different outward forms that unconscious despair, in its "spiritlessness" (SUD 45), can take: "whether the state is a thoroughgoing moribundity, a merely vegetative life, or an intense, energetic life, ... [it] is still despair" (SUD 45). Furthermore, in keeping with earlier analyses of acedia, any form of rest offered by unconscious despair is contrary to the proper rest which is available to a self free from despair (i.e., the person who has faith). "Every human existence that is not conscious of itself as spirit or conscious of itself before God as spirit, every human existence that does not rest transparently in God but vaguely rests in and merges in some abstract universality (state, nation, etc.) ... every such existence is nevertheless despair" (SUD 46).

One might object that the connection with acedia is tenuous, that these parallels are mere superficial resemblances, chiefly because acedia's characteristic object—sorrow over the Divine good—is conspicuously absent. There are two things to say at this point. First, a person in unconscious despair is, by definition, unaware of her true condition, unaware at all that she was created to be spirit and certainly unaware of the Divine good. Consequently, it is unsurprising that we find no explicit mention of a self which, consumed as it is by the sensate, sorrows over or feels weighed down away from the Divine good. Second, a deeper analysis reveals that this form of despair does involve sorrow over a Divine good. If the human self is a relation that is established by God (cf. SUD 14), that self can be seen as a Divine good. This idea is suggested when Anti-Climacus writes, "to have a self, to be a self, is the greatest concession, an infinite concession, given to man, but it is also eternity's claim upon him" (SUD 21). When this self is not properly related to itself and to God, the result is a type of sorrow that Anti-Climacus calls despair. Thus, the object of the aesthete's despair (i.e., being split apart from God and self) is in part this Divine good-even though he is unaware of it.

Unconscious despair is strange; it "cannot be defined [a]esthetically" (SUD 45), that is, understood from the aesthetic sphere. Here, Anti-Climacus turns our attention from the phenomenal axis to the evaluative axis, where we see what may be called an "ethical-religious" evaluation of aesthetic acedia. ${ }^{70}$

68 Anti-Climacus acknowledges that this form is, in keeping with common parlance, "not despair in the strict sense" (SUD 13).

69 (Evans 1990, p. 79).

70 At this point, note (again) how Kierkegaard often lumps together categories, such as the "ethical-religious" (SUD 45), from which certain theoretical complications can arise. Hence it is important not to place too much weight on the stages/spheres as clear categories. 
From this perspective, it is clear why this strange state is yet despair. "It would be stupid to deny," says Anti-Climacus, that, from the aesthetic perspective, "the natural man can and does lead a life very rich in [a]esthetic enjoyment" (SUD 45). Yet an aesthetic evaluation of aesthetic acedia is by itself insufficient for fully explaining the badness of acedia. "[T]he [a]esthetic category of spiritlessness does not provide the criterion for what is and what is not despair; what must be applied is the ethical-religious category: spirit or, negatively, the lack of spirit, spiritlessness" (SUD 45-46). So we move up.

\subsection{Despair of Weakness: In Despair Not to Will to Be Oneself ${ }^{71}$}

All forms of despair from this point on are conscious despair, in greater or lesser degrees. ${ }^{72}$ Despair of weakness comes in two distinct varieties, the first of which is less severe: despair over the earthly or over something earthly (SUD 50ff.) and despair of the eternal or over oneself (SUD 60ff.). We will discuss these in turn.

\subsubsection{Variety 1}

Though in conscious despair, the self in the first variety of despair of weakness is very similar to that in unconscious despair. He lives in immediacy and deals in the dialectics of pleasant/unpleasant and good luck/bad luck (SUD 51). Those who are more purely immediate place their identity in external things like wealth and reputation (SUD 53). These people fall into despair when they lose a particular earthly thing and despair over that particular loss. Those who are more reflective place their identity in their capacities and talents, which are less external but still earthly; here one despairs "not just of this or that, but over the whole of earthly goods" (SUD 60). ${ }^{73}$ Anti-Climacus claims that despair of weakness over the earthly, in either of its severities, "is the most common form of despair" (SUD 57). ${ }^{74}$

With this despair of weakness over the earthly, Anti-Climacus is describing yet another form of aesthetic acedia, very similar to the sort of reflective aesthetic acedia exhibited by the reflective aesthete $\mathrm{A}$ in EO, who is aware of and aims to cancel his boredom. This form of aesthetic acedia requires a higher level of consciousness. Here, one is conscious of one's despair, and to some degree conscious of oneself as spirit, but lacks an "infinite consciousness of the self" (SUD 50). The fact that this person lives a life of immediacy and mistakenly identifies her self in terms of external criteria ensures that she remains within the aesthetic sphere. Furthermore, it is her low level of consciousness regarding her self (a Divine good established by God) that produces the despair.

\subsubsection{Variety 2}

Despair of weakness's second variety (SUD 60ff.) is more severe and rarer (SUD 63): despair of the eternal [and] over oneself. ${ }^{75}$ "This despair," Anti-Climacus remarks, "is a significant step forward. If the

71 Pieper (Pieper 1986; Pieper 1952) and DeYoung (2015) both hint at the connections between this form of despair and acedia, but no one seems to have spelled out the relation in much detail.

72 In order to be conscious of being in despair, Anti-Climacus thinks that the self needs to know what despair is and needs to have a certain level of self-understanding. Both of these elements of knowledge, however, come in degrees (cf. Evans 1990, p. 78); so one can experience this form of despair without a perfect understanding of despair or of oneself. Anti-Climacus also mentions that this form is more intensive than the preceding form of despair because the self has a higher degree of self-consciousness (SUD 48). Nevertheless, this despair is a step closer to the cure, since it is at least conscious of being in despair.

73 The reader will notice that this analysis closely parallels that of the judge in Either/Or II.

74 This apparently contradicts what Anti-Climacus claims earlier (SUD 45), that unconscious despair, "This form of despair (ignorance of it) is the most common in the world." There are two possible explanations. Either Anti-Climacus is restricting the scope of his later claim (SUD 57) to the kinds of despair that are recognized in common parlance as despair, in which case unconscious despair would be excluded from consideration; or perhaps Anti-Climacus means to include unconscious despair in his later claim, which he characterizes as "Despair over the earthly or over something earthly" (SUD 56).

75 Here, Anti-Climacus draws our attention to his use of 'of' in the phrase "despair of the eternal." In a footnote, he explains that what we despair over is the occasion that makes us fall into despair and can be any number of things (e.g., a bad investment, a failed marriage, etc.). On the other hand, what we despair of is "that which, rightly understood, releases us from despair: of the eternal, of salvation, of our own strength, etc." (SUD 61). Part of what makes these lower forms of 
preceding despair was despair in weakness, then this is despair over his weakness, while still remaining in the category" (SUD 61). He who despairs of the eternal "himself understands that it is weakness to make the earthly so important, that it is weakness to despair" (SUD 61), yet he remains frozen in place. "[I]nstead of definitely turning away from despair to faith and humbling himself under his weakness, he entrenches himself in despair and despairs over his weakness" (SUD 61). In one sense it is similar to defiant despair, since "this new despair comes from the self" rather than seemingly "from the outside" as when one loses earthly goods (SUD 62). It is still, however, classified as a despair of weakness because of the nature of the response. It is how one might react as a son who is disinherited by his father: "the self does not want to acknowledge itself after having been so weak ... in despair it does not wish, so to speak, to hear anything about itself" (SUD 62). This response is far from defiantly willing to be a self. ${ }^{76}$

With this form of despair, we find Anti-Climacus' description of ethical acedia-i.e., ethical acedia as diagnosed from the religious sphere (see Figure 1). With a higher consciousness of self, this person has moved out of the aesthetic category of immediacy and seeks to become a unified self-the hallmark of the ethical sphere-yet fails to become a self. The resulting state is psychological tension. On the one hand, there "sits the self, so to speak, watching itself, preoccupied with ... not willing to be itself"; on the other hand, such preoccupation means the self is "yet being self enough to love itself" (SUD 63). No longer an aesthete in immediacy, Anti-Climacus calls this state "inclosing reserve" [Indesluttethed] ... which is the very opposite of immediacy (SUD 63). ${ }^{77}$ In this state, one hides one's despair while carrying on with the externals of life like everything is normal. ${ }^{78}$ "The self-inclosing despairing person goes on living horis succesivis [hour after hour]: even if not lived for eternity, his hours have something to do with the eternal and are concerned with the relation of his self to itself-but he never really gets beyond that" (SUD 64).

Anti-Climacus intimates that this form of despair marks an important point of transition-either to deeper forms of despair or to faith. One can think of this kind of despair as a crossroads of "inclosing reserve" [Indesluttethed's crossroads], whereby the self- "if it does not stop there and just mark time on the spot" (SUD 65)-may feel inclined to choose one of three paths. Going forward, if he does not move on to the first path, "the right road to faith" (SUD 65), the other paths both lead to worse forms of despair. Second, this kind of despair can intensify and become defiant despair, considered in the next section. Third, this kind of despair can "break through and destroy the outward trappings in which such a despairing person has been living out his life as if in an incognito" (SUD 65). With respect to this third path, Anti-Climacus continues, it ultimately branches into two, both of which involve an extreme form of restlessness that is characteristic of acedia:

a person in this kind of despair will hurl himself into life, perhaps into the diversion of great enterprises; he will become a restless spirit whose life certainly leaves its mark, a restless spirit who wants to forget ... Or he will seek oblivion in sensuality, perhaps in dissolute living; in despair he wants to go back to immediacy, but always with the consciousness of the self he does not want to be.

(SUD 65-66)

despair so problematic, says Anti-Climacus, is that a person "so passionately and clearly sees and knows over what he despairs, but of what he despairs evades him" (SUD 61).

76 In Anti-Climacus' own words, "this new despair comes from the self, indirectly-directly from the self, as the counter-pressure (reaction), and it thereby differs from defiance, which comes directly from the self" (SUD 62).

77 The Hongs translate this as "inclosing reserve," but as Evans has noted it literally means "shut-up-ness": "Such a person may be outwardly well-adjusted and sociable, but the outwardness is only a 'false door' that the true self hides behind" (Evans 1990, pp. 80-81). One wonders whether "becoming withdrawn" might also be an appropriate rendering.

78 Here, "our man in despair is sufficiently self-inclosed to keep this matter of the self away from anyone who has no business knowing about it-in other words, everyone-while outwardly he looks every bit 'a real man.' He is a university graduate, husband, father, even an exceptionally competent public officeholder, a respectable father, pleasant company, very gentle to his wife, solicitude personified to his children. And Christian?-Well, yes, he is that, too, but prefers not to talk about it, although with a certain wistful joy he likes to see that his wife is occupied with religion to her upbuilding" (SUD 63-64). 
Either branch on this third path returns the self to the aesthetic sphere: one either seeks fulfillment in one's own accomplishments or seeks oblivion in sensuality, but in both the self wants to ignore the eternal. ${ }^{79}$ Clearly a descent to the aesthetic sphere will not leave the self unmarked; it still has some higher degree of self-knowledge, "always with the consciousness of the self he does not want to be" (SUD 66) - and indeed, in his weakness, cannot bring himself to be. Hence this is far more damaging to one's soul than unconscious despair simply, because it heightens one's culpability. (And hence Anti-Climacus' disclaimer that "No despair is entirely free of defiance" (SUD 50).) Despite the self's descent to the aesthetic sphere, this state must nevertheless be recognized as a kind of ethical acedia; even though one attempts to solve one's despair by aesthetic means, one does so from a place of willful ignorance of the eternal..$^{80}$

It is possible that a religious acedia may also be found lurking in the despair of weakness of the eternal (60ff.) which we have been discussing. One might argue the following way. Just as, by taking the third path at Indesluttethed's crossroads, ethical acedia can manifest as a return to the aesthetic sphere, so religious acedia can manifest as a return to the ethical sphere. The person of faith in the religious sphere, in contrast to the despairing person, "definitely turn[s] away from despair to faith and humbl[es] himself under his weakness" (SUD 61). Supposing that, even in the religious sphere, the person of faith is presented with fresh opportunities to realize her own weakness, she faces the decision all over again: she can remain in a state of humility and faith, or she can fall into despair over her weakness, which would involve a return to the ethical sphere. ${ }^{81}$ Perhaps this is what Anti-Climacus has in mind in Part Two with the sin of despairing over one's sin (SUD 109ff.). ${ }^{82}$

\subsection{Defiant Despair: In Despair to Will to Be Oneself}

With the next form of despair-defiant despair-we encounter a more intensive despair which requires the will's active participation. While it is true that "No despair is entirely free of defiance" (SUD 50), defiant despair is characterized by its defiance. Rather than passive lack of willing ("not to will to be oneself", whether velleity or abulia as in acedia's first effect, listlessness), it is active willfulness ("to will to be oneself"). Indeed, one arrives here via the second path at Indesluttethed's crossroads: no longer in immediacy, the self in inclosing reserve is the subject of despair which intensifies to become defiant despair. Defiant despair, Anti-Climacus says, is "really despair through the aid of the eternal," albeit "the despairing misuse of the eternal within the self" (SUD 67). Rather than taking the first path, where "also through the aid of the eternal ... the self has the courage to lose itself in order to win itself" (SUD 67; cf. Mt. 16.26, Mk. 8.36), the self in defiant despair "is unwilling to begin with losing itself but wills to be itself" (SUD 67).

79 These branches parallel neatly with acedia's twofold effect: producing either a restless person, who desires to make some sort of impression or just to forget, or a person who seeks an improper rest in the form of a return to a lower self. Either way, the self here never attains true rest in God (cf. SUD 49).

80 We see another kind of ethical acedia when the self remains at these crossroads, remains in the ethical sphere. For this self, "who in his inclosing reserve marks time on the spot" (SUD 66) and who "entrenches himself in despair and despairs over his weakness" (SUD 61), there are two possible outcomes. The greatest danger is suicide, for the self isolates itself from others; otherwise, the completely inclosed person may confide his weakness to someone, though suicide still presents a danger (SUD 66). There is yet another connection to acedia here in the unfortunate, perhaps surprising, association between monastic acedia and suicide. As one historian remarks, "A melancholy leading to desperation, and known to theologians under the name of 'acedia,' was not uncommon in monasteries, and most of the recorded instances of mediæval suicides in Catholicism were by monks" (Lecky 1869, pp. 55-56).

81 The robustness of this possibility seems to hinge upon both (a) what one's theological commitments will permit and (b) just what one makes of the religious sphere (i.e., what is it to definitely turn away from despair?).

82 No doubt the comparisons are getting more and more complex the higher one goes, but this is no fault of Kierkegaard. This complexity arises from the Christian tradition itself, which, as we discussed in Section 1, identified acedia as a capital vice-associating it with numerous "offspring" vices. Thus, complexity arises in Anti-Climacus' analysis because going further up the degrees of despair, it is more difficult to tell whether he is describing phenomena the tradition identifies as acedia proper or one of acedia's daughter vices. So, while Anti-Climacus may in his psychological analysis of despair include these further vices of acedia along with acedia proper within a single kind of despair, we can still conceptually distinguish between them and note that acedia proper serves as the origin for these others. Returning to where we left off, then, it becomes easier to digest how the higher, more willful kinds of despair are still, at their roots, kinds of acedia. 
What is this self it wills to be? Certainly not the self given to him: no, "he himself wants to compose his self" (SUD 68). At this level of despair, the self is more conscious of "what despair is and that one's state is despair" (SUD 67); likewise, the self is more conscious that it is an infinite self. "This infinite self, however, is really only the most abstract form, the most abstract possibility of the self" (SUD 68). Here the self imagines, in its own estimation, what perfect self it could be-yet with no input from its Creator, "severing the self from any relation to a power that has established it, or severing it from the idea that there is such a power" (SUD 68). Instead, it "wants to be master of itself or to create itself, to make his self into the self he wants to be" (SUD 68). Once again, cases of defiant despair come in degrees of severity. ${ }^{83}$ In less severe cases, the self is an "acting self," actively courting "imaginative constructions" of itself. In more severe cases, the (apparently more mature) self is "acted upon" and passively hindered by the temporal, ${ }^{84}$ overestimating this or that temporal difficulty or imperfection, it despairs of the eternal's help and consolation (SUD 70). In both, however, the self wills to be oneself. ${ }^{85}$

We believe, especially considering the heightened awareness, and subsequent rejection, of the infinite self as given by an eternal Sovereign power, that this level of defiant despair approaches the mortal sin of acedia. Acedia is a mortal sin, properly speaking, when it is "complete" [perfecta]-i.e., when one's reason has consented to the act (ST II.II.35.3.co). ${ }^{86}$ When this happens, reason "consents in the dislike, horror and detestation of the Divine good, on account of the flesh utterly prevailing over the spirit" (ST II.II.35.3.co). Anti-Climacus himself seems to affirm the distinction when he says, in his discussion of the connection between despair and $\sin$, "sin is not the turbulence of flesh and blood, but is the spirit's consent to it" (SUD 82).

It is difficult to say whether with this acedia one properly inhabits the religious sphere-especially Religiousness B (cf. CUP 555ff.) -nevertheless, we shall use the nomenclature religious acedia to describe acedia at the level of defiant despair. It must be said, however, that not all instances of religious acedia are mortal sin. As Thomas acknowledges, acedia is found even in "perfected men": "In saintly men one finds some incomplete movements of acedia, which nonetheless do not reach all the way to the consent of reason" (ST II.II.35.3.ad3). This is perhaps the case with the possible religious acedia we discussed earlier with respect to despair of weakness; its being a venial sin, "a mere beginning of sin in the sensuality alone, without attaining to the consent of reason" (II.II.35.3.co), would explain why it is better classified as weakness than as defiance.

\subsection{Demonic Despair: In Despair to Will to Be One's Own Self7}

Demonic despair is intensified defiant despair, at the highest level of consciousness, aware of God and of his self as given by God, but utterly rejecting the whole thing. "Himself is what he wills to be. He began with the infinite abstraction of the self, and now he has finally become so concrete that it would be impossible to become eternal in that sense; nevertheless, he wills in despair to be himself" (SUD 72). The self here becomes sour and enraged. ${ }^{88}$ It seems entry to demonic despair comes via that defiant despair which despairs of the eternal. Wishing to transcend the temporal, he is nevertheless

83 This division into less and more severe defiant despair parallels the preceding tier, despair of weakness, with its division of despairing over the earthly and despairing of the eternal, respectively.

84 Though it seems less defiant, here the self is being "acted upon" by the temporal because it is more drawn to the eternal. A refusal of the eternal's help despite this marks this state as more defiant.

85 Anti-Climacus explains, "But this is also a form of the despair, to be unwilling to hope in the possibility that an earthly need, a temporal cross, can come to an end. The despairing person who in despair wills to be himself is unwilling to do that." (SUD 70-71).

86 Otherwise, "if the sin be a mere beginning of $\sin$ in the sensuality alone, without attaining to the consent of reason" (II.II.35.3.co), then it is merely a venial sin.

87 To borrow a locution from Jeff Hanson. Although Anti-Climacus uses the same for this as with the other kinds of defiant despair-"despair to will to be oneself" (SUD 68) - it is clear that he has in mind something quite strong. Instead of "oneself", abstractly, the self wills to be "himself" concretely (SUD 72).

88 Curiously, Wenzel points to a common Scholastic pseudo-etymology for acedia which had impact on the tradition: acidus ("sour"), at one time its "standard derivation" (Wenzel 1960, p. 54). 
hampered by some particular pain or distress "that does not allow itself to be taken away from or separated from his concrete self" (SUD 72) And so he obsesses over this torment until finally it becomes a demonic rage. "Once he would gladly have given everything to be rid of this agony, but he was kept waiting; now it is too late" (SUD 72). Here, Indesluttethed becomes so inclosing, so reserved, it "could be called an inwardness with a jammed lock" (SUD 72). Such a picture of active and informed rejection of the Divine good in exchange for one's own self can be nothing short of the mortal sin of acedia.

\section{Conclusions}

We began this paper by pointing out that numerous connections have been made between Kierkegaardian concepts and the capital vice of acedia, and that there is a need for clarity and consensus in the project. We have taken a small step toward this goal by looking at two of Kierkegaard's texts which offer the most direct parallels with acedia. In Either/Or, we saw that the notions of Tungsind and Kjedsommelighed seemed to capture all of the important features of the traditional conception of acedia. Similarly, the various forms of despair in The Sickness Unto Death captures those important features as well. While the parallels are strong in each case, it might seem that we have merely contributed to the disarray that has characterized the project of bringing Kierkegaard into conversation with the traditional view of acedia.

There are two things to be said at this point. First, as this paper has revealed, a certain level of disarray is appropriate. Kierkegaard is clearly addressing the phenomenon of acedia in different ways and with different terminology. Second, this disarray is precisely what makes Kierkegaard's view of acedia so insightful and illuminating. He does not examine the phenomenon from one perspective and then move on. Instead, he recognizes the complexities of acedia and seeks to appreciate them in his analysis. Part of the genius of Kierkegaard is to examine different spheres of life from the inside, granting them a kind of integrity without simply reducing them to another sphere's analysis. The acedia found in each sphere is similar. Kierkegaard helps us see the perspectival nature of acedia by examining each form on its own terms and from higher spheres. Thus, Kierkegaard's analysis helps us avoid the temptation of reducing the morally and experientially complex acedia into a single phenomenon which fails to do justice to the diverse manifestations.

Thus, in Either/Or we encounter a brilliant depiction of the phenomenon as it appears in the aesthetic life (Part I) and an ethical analysis of that depiction (Part II). Then, in The Sickness Unto Death, Anti-Climacus presents religious analyses of the phenomenon in each sphere of life. He elucidates an aesthetic version of acedia in two forms of despair: despair that is ignorant of being despair and the first variety of despair in weakness. The second variety of despair in weakness provides an analysis of acedia as it can appear in the ethical or religious spheres. The presence of faith is the criterion for determining which type of acedia is present: if the despair comes after the state of faith, it is religious acedia. While each analysis is important, Kierkegaard gives us reason to prioritize the last. In discussing the idea of spiritlessness in The Sickness Unto Death, Anti-Climacus makes the following remarks:

the [a]esthetic conception of spiritlessness by no means provides the criterion for judging what is despair and what is not, which, incidentally, is quite in order, for if what is spirit cannot be defined [a]esthetically, how can the [a]esthetic answer a question that simply does not exist for it ... No, the [a]esthetic category of spiritlessness does not provide the criterion for what is and what is not despair; what must be applied is the ethical-religious category.

(SUD 45)

Thus, while the earlier analyses contain important insights, only the perspective represented by Anti-Climacus can analyze the phenomenon of acedia in all its manifestations.

In conclusion, Kierkegaard's perspectival discussions of acedia make an important contribution to our understanding of this perennial topic for two reasons. First, Kierkegaard fills a lacuna in the conceptual analysis by exploring the ways in which acedia appears outside the religious life. For the Desert Fathers and for Aquinas, discussions of acedia were limited to the struggles of believers. Second, 
the perspectival character of Kierkegaard's analysis gives us a much better understanding of the phenomenon. This feature of his account can be extremely helpful in our attempts to counsel those who are in the grip of this destructive vice. ${ }^{89}$

Author Contributions: Conceptualization, J.B., B.D. and D.M.; writing—original draft preparation, B.D., J.B. and D.M.; writing-review \& editing, D.M., J.B. and B.D. All authors have read and agreed to the published version of the manuscript.

Funding: This research received no external funding.

Acknowledgments: The authors wish to express gratitude to C. Stephen Evans for comments on earlier versions of this paper and for his several graduate seminars on Kierkegaard.

Conflicts of Interest: The authors declare no conflict of interest.

\section{References}

Aquinas, Thomas. 1947. Summa Theologica of Saint Thomas Aquinas. 5 vols. Trans. Fathers of the English Dominican Province. New York: Benziger Bros. Press.

Bloomfield, Morton W. 1952. The Seven Deadly Sins: An Introduction to The History of A Religious Concept, With Special Reference To Medieval English Literature. East Lansing: Michigan State College Press.

Cappelørn, N. J. 2008. Spleen Essentially Canceled-Yet a Little Spleen Retained. Translated by K. Brian Söderquist. In Ethics, Love, and Faith in Kierkegaard. Edited by Edward F. Mooney. Bloomington: Indiana University Press.

Cassian, John. 1894. Institutes of the Coenobia. Translated by Edgar C. S. Gibson. In A Select Library of Nicene and Post-Nicene Fathers of the Christian Church. Second Series; New York: Christian Literature, Volume 11.

Colón, Susan E. 2011. 'This Twittering World': T. S. Eliot and Acedia. Religion and Literature 43: 69-90.

DeYoung, Rebecca Konyndyk. 2009. Glittering Vices: A New Look at the Seven Deadly Sins and Their Remedies. Grand Rapids: Brazos Press.

DeYoung, Rebecca Konyndyk. 2015. The Roots of Despair. Res Philosophica 92: 829-54. [CrossRef]

Eliot, T. S. 1948. Four Quartets. London: Faber and Faber. First published 1943.

Eliot, T. S. 1935. Murder in the Cathedral. New York: Harcourt Brace and Company.

Evans, C. Stephen. 1990. Søren Kierkegaard's Christian Psychology. Grand Rapids: Zondervan.

Ferguson, Harvie. 1994. Melancholy and the Critique of Modernity: Søren Kierkegaard's Religious Psychology. New York: Routledge.

Furtak, Rick Anthony. 2009. Marcus Aurelius: Kierkegaard's Use and Abuse of the Stoic Emperor. In Kierkegaard Research: Sources, Reception, and Resources. Volume 3: Kierkegaard and the Roman World. Edited by Jon Stewart. Farnham: Ashgate Publishing.

Gregory, Pope St., the Great. 1844. Moralia in Iob. Translated by John Henry Parker. Oxford: Oxford University Press.

Harmless, S. J. William. 2004. Desert Christians: An Introduction to the Literature of Early Monasticism. Oxford: Oxford University Press.

Harries, Karsten. 2010. Between Nihilism and Faith: A Commentary on Either/Or. Kierkegaard Studies: Monograph Series; Edited by Niels Jørgen Cappelørn and Hermann Deuser. Berlin: De Gruyter.

Huxley, Aldous. 1928. Accidie. In On the Margin: Notes and Essays. London: Chatto and Windus, pp. 18-25. First published 1923.

Kierkegaard, Søren. 1980. The Sickness Unto Death. Translated by Howard V. Hong, and Edna H. Hong. Princeton: Princeton University Press.

Kierkegaard, Søren. 1987a. Either/Or: Part I. Translated by Howard V. Hong, and Edna H. Hong. Princeton: Princeton University Press.

Kierkegaard, Søren. 1987b. Either/Or: Part II. Translated by Howard V. Hong, and Edna H. Hong. Princeton: Princeton University Press.

Kierkegaard, Søren. 1995. Works of Love. Translated by Howard V. Hong, and Edna H. Hong. Princeton: Princeton University Press.

89 Though we have not addressed it much in this paper, Kierkegaard has much to offer on the topic of the remedies for acedia. We hope to consider this aspect of his view in future work. 
Kuhn, Reinhard. 1976. The Demon of Noontide: Ennui in Western Literature. Princeton: Princeton University Press. Lecky, Wiiliam Edward Hartpole. 1869. History of European Morals. London: Longmans, Green, and Co., vol. 2. McCarthy, Vincent A. 1978. The Phenomenology of Moods in Kierkegaard. The Hague: Martinus Nijhoff.

McDonald, William. 2009. Kierkegaard's Demonic Boredom. In Essays on Boredom and Modernity. Edited by Barbara D. Pezze and Carlo Salzani. Amsterdam: Rodopi.

Migne, Jacques-Paul. 1846. Patrologiæ cursus completus: Series latina. Tome 49: Joannis Cassiani, Tomus Prior. Paris: Apud Garnieri Fratres, editores et J.-P. Migne successores.

Migne, Jacques-Paul. 1863. Patrologiæ cursus completus: Series græca. Tome 40: Patres Ægyptii, Sæculi IV. Paris: Apud J.-P. Migne Editorem.

Miner, Robert. 2009. Thomas Aquinas on the Passions: A Study of Summa Theologix 1a2ae 22-48. Cambridge: Cambridge University Press.

Paget, Francis. 1891. The Spirit of Discipline, Together with an Introductory Essay Concerning Accidie. London: Longmans, Green, \& Co.

Pattison, George. 2013. Kierkegaard \& the Quest for the Unambiguous Life. Oxford: Oxford University Press.

Pieper, Josef. 1986. On Hope. Translated by Mary Frances McCarthy. San Francisco: Ignatius Press. First published 1935. Pieper, Josef. 1952. Leisure: The Basis of Culture. Translated by Alexander Dru. San Francisco: Ignatius Press. First published 1948.

Podmore, Simon. 2011. Kierkegaard and the Self Before God. Bloomington: Indiana University Press.

Podmore, Simon. 2013. Struggling With God: Kierkegaard and the Temptation of Spiritual Trial. Cambridge: James Clarke.

Puchniak, Robert. 2008. Augustine: Kiekegaard's Tempered Admiration of Augustine. In Kierkegaard Research: Sources, Reception and Resources Volume 4, Kierkegaard and the Patristic and Medieval Traditions. New York: Routledge, pp. 11-22.

Tzamalikos, Panayiotis. 2012. The Real Cassian Revisited: Monastic Life, Greek Paideia, and Origenism in the Sixth Century. Leiden: Brill.

Vlachos, Hierotheos. 1994. Orthodox Psychotherapy: The Science of the Fathers. Translated by Esther Williams. Levadia: Birth of the Theotokos Monastery.

Waugh, Evelyn. 1999. Brideshead Revisited. New York: Penguin Books. First published 1945.

Wenzel, Siegfried. 1960. The Sin of Sloth: Acedia in Medieval Thought and Literature. Chapel Hill: University of North Carolina Press.

(C) 2020 by the authors. Licensee MDPI, Basel, Switzerland. This article is an open access article distributed under the terms and conditions of the Creative Commons Attribution (CC BY) license (http://creativecommons.org/licenses/by/4.0/). 